\title{
CLINICO-BIOCHEMICAL STUDY OF PATIENTS WITH THYROID SWELLING AT A TERTIARY CARE CENTRE
}

\author{
Praveen Kumar1, Ved Prakash², Sajjad Ahsan³, Kalpana Chandra ${ }^{4}$, Amrita Kumari ${ }^{5}$ \\ ${ }_{1}^{1}$ Associate Professor, Department of General Medicine, IGIMS, Patna, Bihar, India. \\ ${ }^{2}$ Assistant Professor, Department of Endocrinology, IGIMS, Patna, Bihar, India. \\ ${ }^{3}$ Senior Resident, Department of Endocrinology, IGIMS, Patna, Bihar, India. \\ ${ }^{4}$ Assistant Professor, Department of Pathology, IGIMS, Patna, Bihar, India. \\ ${ }^{5}$ Ex. Senior Resident, Department of Anatomy, IGIMS, Patna, Bihar, India.
}

\section{ABSTRACT}

\section{BACKGROUND}

Thyroid is one of the largest endocrine organs, associated with cell differentiation, development and metabolic homeostasis in body. Thyroid swelling is a common thyroid disorder. This study was intended to find out common symptoms of patient with thyroid swelling, their thyroid hormone status and FNAC.

\section{MATERIALS AND METHODS}

This is a prospective observational study. 100 consecutive patients of neck swelling attending to endocrinology OPD, general medicine OPD or admitted in medical ward at IGIMS, Patna were included in the study.

\section{RESULTS}

Thyroid swelling commonly affects females. It most commonly affected 31 - 40 years' age group followed by $11-20$ and $21-30$. After neck swelling, symptoms of hyperthyroidism were present in 23 cases and symptoms of hypothyroidism in 10 cases. Most common TFT function abnormality was hyperthyroidism in 44 cases followed by hypothyroidism in 28 cases. Most common abnormality on FNAC was colloid goitre. TPO antibody was done in 8 cases and was high.

\section{CONCLUSION}

Thyroid swelling is a very important endocrine manifestation commonly affecting female patients of middle age group, commonly presenting as neck swelling with features of hyperthyroidism or hypothyroidism. Colloid goitre is the commonest cytological abnormality.

\section{KEY WORDS}

Neck Swelling, Thyroid Swelling, Thyroid Function Test.

HOW TO CITE THIS ARTICLE: Kumar P, Prakash V, Ahsan S, et al. Clinico-biochemical study of patients with thyroid swelling at a tertiary care centre. J. Evolution Med. Dent. Sci. 2018;7(27):3096-3098, DOI: 10.14260/jemds/2018/695

\section{BACKGROUND}

Thyroid is one of the largest endocrine organs weighing about 15 - 20 grams in adult. The gland is formed of follicle, which is filled with colloid. Colloid contains thyroglobulin (Tg) molecule, in which thyroid hormones are present.[1] Thyroid hormones are primarily responsible for cell differentiation during development and maintaining metabolic homeostasis in adult.[2] Thyroid diseases are among the commonest endocrine disorders worldwide as well as in India, affecting 42 million people in India.[3]

Goitre is a clinical term used for thyroid enlargement above the gender and age specific reference range. It may be endemic or sporadic.[4] The disease entity endemic goitre is defined as when colloid goitre due to iodine deficiency affect $>5 \%$ of population. [2] Endemic goitre is common in the Himalayas, the Andes and part of Africa. ${ }^{[5]}$ The disease entity of sporadic non-toxic goitre is defined as benign enlargement

'Financial or Other Competing Interest': None.

Submission 24-05-2018, Peer Review 18-06-2018,

Acceptance 23-06-2018, Published 02-07-2018.

Corresponding Author:

Dr. Ved Prakash,

Assistant Professor,

Department of Endocrinology,

IGIMS, Patna, Bihar, India.

E-mail: vedprakashims@gmail.com

DOI: $10.14260 /$ jemds $/ 2018 / 695$

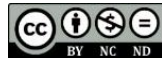

of thyroid gland of unknown cause in euthyroid condition living in area without endemic goitre. It is diagnosis of exclusion. Sporadic goitre may be diffuse or nodular.[4] Ultrasound is the most accurate method to assess thyroid size.[5] Iodine deficiency, biosynthesis defect, autoimmune disease, neoplastic and nodular diseases can lead to thyroid swelling or goitre.[3] This study was intended to find out common symptoms of patient with thyroid swelling, their thyroid hormone status and FNAC.

\section{Objective of Study}

The present study was undertaken to evaluate the clinical features, thyroid hormone status and FNAC of patients with thyroid swelling.

\section{Study Design}

A prospective observational study.

\section{MATERIALS AND METHODS}

A prospective observational study was done on patient of thyroid swelling attending to endocrinology OPD, general medicine OPD or admitted in medical ward at IGIMS, Patna, Bihar.

100 consecutive patients of anterior neck swelling attending to endocrinology OPD, general medicine OPD or admitted in medical ward at IGIMS, Patna were included for the study. Selected patients were subjected to history, clinical examination, routine investigation, thyroid function test, TPO 
antibody in selected cases, USG neck in selected cases and FNAC in selected cases.

\section{Statistical Analysis}

Descriptive statistics were calculated. Numbers and percentages were enumerated for age, sex, clinical findings, thyroid function test and FNAC.

\section{RESULTS}

We included 100 cases for this study. The patients were subjected to a thorough clinical examination, investigation and a structured proforma was filled for each case. Results are summarised as follows-

1) Sex-wise distribution (Fig. 1)- Out of 100 cases, 86 were females and 14 were males with female-to-male ratio of 6.14: 1 .

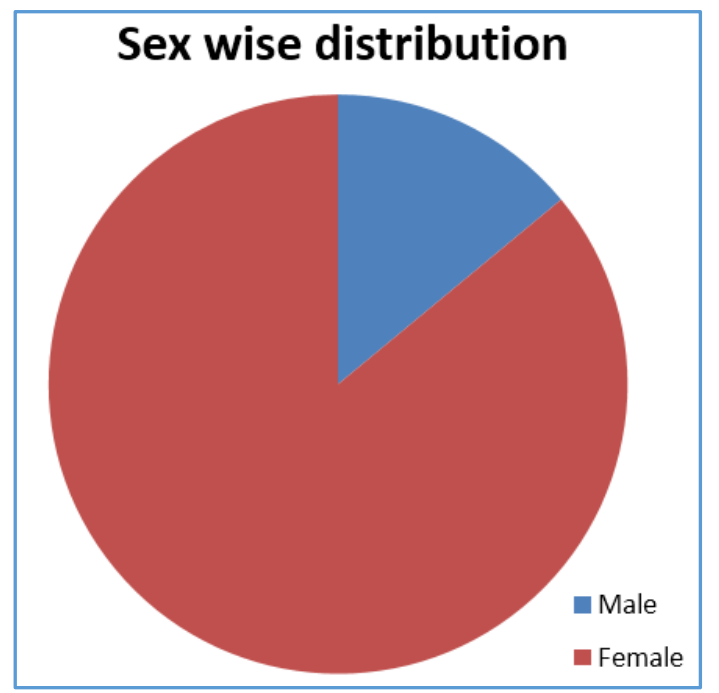

Figure 1

2) Age-wise distribution (Table 1)- Thyroid swellings were prevalent in all age group with age range of 14 to 73 years. The commonest age group was 31 to 40 years, contributing $26 \%$ followed by $24 \%$ each in 11 to 20 and 21 to 30 .

\begin{tabular}{|c|c|c|c|c|c|}
\hline $\begin{array}{c}\text { Sl. } \\
\text { No. }\end{array}$ & $\begin{array}{c}\text { Age } \\
\text { Interval }\end{array}$ & $\begin{array}{c}\text { Sex } \\
\text { Wise } \\
\text { Frequency }\end{array}$ & $\begin{array}{c}\text { Sex Wise } \\
\text { Frequency } \\
\text { (\% of Total } \\
\text { Population) }\end{array}$ & $\begin{array}{c}\text { Total } \\
\text { Frequency }\end{array}$ & $\begin{array}{c}\text { Total } \\
\text { Frequency } \\
\text { in \% }\end{array}$ \\
\hline 1 & $11-20$ & $\begin{array}{c}\text { Male- 2 } \\
\text { Female- 22 }\end{array}$ & $\begin{array}{c}\text { Male- 2\% } \\
\text { Female- 22\% }\end{array}$ & 24 & $24 \%$ \\
\hline 2 & $21-30$ & $\begin{array}{c}\text { Male- 6 } \\
\text { Female- 18 }\end{array}$ & $\begin{array}{c}\text { Male- 6\% } \\
\text { Female- 18\% }\end{array}$ & 24 & $24 \%$ \\
\hline 3 & $31-40$ & $\begin{array}{c}\text { Male- 3 } \\
\text { Female- 23 }\end{array}$ & $\begin{array}{c}\text { Male- 3\% } \\
\text { Female- 23\% }\end{array}$ & 26 & $26 \%$ \\
\hline 4 & $41-50$ & $\begin{array}{c}\text { Male- 0 } \\
\text { Female- 15 }\end{array}$ & $\begin{array}{c}\text { Male- 0\% } \\
\text { Female- 15\% }\end{array}$ & 15 & $15 \%$ \\
\hline 5 & $51-60$ & $\begin{array}{c}\text { Male- 1 } \\
\text { Female- 4 }\end{array}$ & $\begin{array}{c}\text { Male- 1\% } \\
\text { Female- 4\% }\end{array}$ & 5 & $5 \%$ \\
\hline 7 & $71-70$ & $\begin{array}{c}\text { Male- 1 } \\
\text { Female- 0 }\end{array}$ & $\begin{array}{c}\text { Male- 1\% } \\
\text { Female- 0\% }\end{array}$ & 1 & $1 \%$ \\
\hline \multicolumn{7}{|c|}{$\begin{array}{c}\text { Male- 1 } \\
\text { Female- 4 }\end{array}$} & $\begin{array}{c}\text { Male- 1\% } \\
\text { Female- 4\% }\end{array}$ & 5 & $5 \%$ \\
\hline
\end{tabular}

3) Clinical feature (Table 2)- Out of 100 cases, neck swelling was present in all cases, symptoms of hyperthyroidism in $23 \%$ cases and symptoms of hypothyroidism in $10 \%$ cases.

\begin{tabular}{|c|c|c|}
\hline Clinical Feature & Frequency & $\begin{array}{c}\text { Frequency in } \\
\text { Percentage }\end{array}$ \\
\hline Neck swelling & 100 & $100 \%$ \\
\hline $\begin{array}{c}\text { Symptoms of } \\
\text { hyperthyroidism }\end{array}$ & 23 & $23 \%$ \\
\hline $\begin{array}{c}\text { Symptoms of } \\
\text { hypothyroidism }\end{array}$ & 10 & $10 \%$ \\
\hline \multicolumn{3}{|c|}{ Table 2 } \\
\hline
\end{tabular}

4) Thyroid function test (Table 3)- Thyroid function test was done in all cases. $44 \%$ patients were having hyperthyroidism followed by hypothyroidism in $28 \%$ patients, subclinical hypothyroidism in $10 \%$ cases and euthyroid state in $18 \%$ patients.

\begin{tabular}{|c|c|c|c|}
\hline Sl. No. & TFT & Frequency & Frequency in \% \\
\hline 1 & Hyperthyroidism & 44 & $44 \%$ \\
\hline 2 & Hypothyroidism & 28 & $28 \%$ \\
\hline 3 & $\begin{array}{c}\text { Subclinical } \\
\text { hypothyroidism }\end{array}$ & 10 & $10 \%$ \\
\hline 4 & Euthyroid & 18 & $18 \%$ \\
\hline \multicolumn{4}{|c|}{ Table 3 } \\
\hline
\end{tabular}

5) FNAC of thyroid gland (Table 4). FNAC was done in 56 cases. Colloid goitre was the most common pathology followed by hyperplasic/ toxic nodule.

\begin{tabular}{|c|c|c|c|}
\hline $\begin{array}{r}\text { Sl. } \\
\text { No. }\end{array}$ & FNAC Report & $\begin{array}{c}\text { No. of } \\
\text { Patients }\end{array}$ & $\begin{array}{c}\text { Number in } \\
\text { Percentage (Out } \\
\text { of 56 FNAC Cases) }\end{array}$ \\
\hline 1 & Colloid goitre & 20 & $35.7 \%$ \\
\hline 2 & Hashimoto thyroiditis & 10 & $17.8 \%$ \\
\hline 3 & Lymphocytic thyroiditis & 10 & $17.8 \%$ \\
\hline 4 & Hyperplastic nodule/ toxic & 14 & $25 \%$ \\
\hline 5 & $\begin{array}{c}\text { Subacute thyroiditis/ De- } \\
\text { Quervain's thyroiditis }\end{array}$ & 2 & $3.57 \%$ \\
\hline \multicolumn{3}{|c|}{ Table 4 } \\
\hline
\end{tabular}

6) TPO antibody testing was done in 8 cases and the values were in the range of 189 to $>1300 \mathrm{IU}$.

\section{DISCUSSION}

We conducted a study on 100 consecutive patients of neck swelling attending to endocrinology OPD, general medicine OPD or admitted in medical ward at IGIMS, Patna.

Thyroid enlargement commonly affects women more than men.[2] In our study of 100 cases of neck swelling, 86 were female and 14 were male with female-to-male ratio of 6.14: 1. In a study conducted by Hanushraj $\mathrm{R}$ et al $77 \%$ patients of thyroid swelling were female and $23 \%$ were male. [3] Kartha PP and Sadasivan S in their study observed a striking female predominance in thyroid diseases with females nine times more affected than males.[6]

In our study, thyroid swelling was prevalent in all age group with age ranges from 14 to 73 years. The commonest age group was 31 to 40 years contributing $26 \%$ followed by $24 \%$ in 11 to 20 and 21 to 30 age groups. In the study conducted by Hanushraj R et al, $26.66 \%$ patients were in the 
age group of 31 - 40 and 41 - 50 years. Most of the male patients belonged to the age group of $41-50$ and most of the female patients belonged to the age group of $31-40$ years. ${ }^{[3]}$ Kartha PP and Sadasivan S in their study observed that 40-50 yrs. was the most common age group followed by 30 - 39 yrs. The mean age was 42.25 years. [6]

Thyroid swelling commonly presents with neck swelling, sensation of discomfort, compressive symptoms such as dysphagia, features of superior vena caval syndrome, features of hypothyroidism or hyperthyroidism.[5] In our study neck swelling was present in all cases, symptoms of hyperthyroidism in 23 cases and symptoms of hypothyroidism in 10 cases. In the study conducted by Hanushraj $\mathrm{R}$ et al, symptoms suggestive of hypothyroidism in $36.67 \%$, neither of hypo or hyperthyroidism in $36.67 \%$ and predominantly hyperthyroidism in $26.67 \%$.[3]

In our cases, thyroid function test was done in all cases. $44 \%$ patients were having hyperthyroidism followed by hypothyroidism in $28 \%$ patients, subclinical hypothyroidism in $10 \%$ cases and euthyroid in $18 \%$ patients. In the study conducted by Hanushraj R et al $40 \%$ were in euthyroid state, $26.6 \%$ were in hypothyroid state and $10 \%$ were in hyperthyroidism state.[[3] Kartha PP and Sadasivan S in their study observed $63.7 \%$ cases with euthyroid state, $33.4 \%$ cases with hypothyroidism and $2.9 \%$ cases with hyperthyroidism.[6]

FNAC of thyroid gland was done in 56 cases. Out of 56 cases, colloid goitre was the most common pathology in $35.7 \%$ cases, hyperplasic nodule/ toxic nodule in $25 \%$ cases, Hashimoto thyroiditis in $17.8 \%$ cases, lymphocytic thyroiditis in $17.8 \%$ cases and subacute thyroiditis (De Quervain's thyroiditis) in $3.57 \%$ cases. In the study conducted by Hanushraj R et al, FNAC showed colloid goitre in 30\% cases followed by Hashimoto's thyroiditis in $26.67 \%$ cases. ${ }^{[3]}$ Kartha PP and Sadasivan S in their study observed colloid goitre, lymphocytic thyroiditis, Hashimoto's thyroiditis, colloid goitre with thyroiditis, colloid goitre with cellular nodule, follicular neoplasm, papillary carcinoma and miscellaneous are present in $61.4 \%, 10.3 \%, 3.9 \%, 3.2 \%$, $4.2 \%, 5.8 \%, 9.2 \%$ and 1.9 respectively. ${ }^{[6]}$

In colloid goitre there is biosynthetic defect and iodine deficiency with reduced thyroid hormone synthesis and secondary increase in TSH level with thyroid enlargement.[2] In Graves' disease thyroid stimulating immunoglobulin (TSI) binds to TSH receptor, which stimulates thyroid hormone production with hyperplasia and hypertrophy of follicular cell leading to thyroid enlargement. [7] The goitrous form of Hashimoto's thyroiditis occur because of acquired defect in hormone synthesis with elevated level of TSH. There is also lymphocytic infiltration and immune system induced growth factor leading to thyroid enlargement in Hashimoto's thyroiditis. Nodular disease is characterised by the disordered growth of thyroid gland cells with gradual development of fibrosis.[2]

In our study, TPO antibody testing was done in 8 cases and the values were in the range of 189 to $>1300$ IU. In their study, Hanushraj R et al did TPO antibody in 30 cases. They observed high TPO antibody in 16 cases and normal level in 14 cases.[3]

\begin{tabular}{|c|c|c|}
\hline Sl. No. & Abbreviations & Full Form \\
\hline 1 & FNAC & Fine Needle Aspiration Cytology \\
\hline 2 & OPD & Outpatient Department \\
\hline 3 & TFT & Thyroid Function Test \\
\hline 4 & TPO antibody & Thyroid Peroxidase Antibody \\
\hline 5 & USG & Ultrasonography \\
\hline 6 & TSH & Thyroid Stimulating Hormone \\
\hline \multicolumn{3}{|c|}{ Abbreviations } \\
\hline
\end{tabular}

\section{CONCLUSION}

Thyroid swelling is a very important endocrine manifestation commonly affecting female patients of middle age group, commonly presenting as neck swelling with features of hyperthyroidism or hypothyroidism. Colloid goitre is the commonest cytological abnormality.

\section{ACKNOWLEDGEMENT}

I take this opportunity to extend my gratitude and sincere thanks to all those who helped me to complete this study.

I am highly thankful to Departments of Endocrinology, General Medicine, Biochemistry and Pathology for providing me adequate facilities which helped me to carry out this study.

I owe great sense of indebtedness to dean IGIMS, Patna for permitting me to carry out this study.

\section{REFERENCES}

[1] Tondon N, Garg G. Disorders of thyroid gland. In: Munjal YP, editor in chief. API text book of medicine. 9th edn. New Delhi: Jaypee Brothers 2012: p. 419-29.

[2] Jameson LJ, Mandel JS, Weetman PA. Disorders of thyroid gland. In: Kasper LD, Fauci SA, Hauser LS, et al. eds. Harrison's Principles of internal medicine. 19th edn. McGraw-Hill Education: 2015: p. 2283-308.

[3] Hanshuraj R, Suudharsan S, Balasubramaniyan S, et al. A clinical study on patients presenting with thyroid swelling and its correlation with TFT, USG, FNAC and anti TPO antibodies. SSRG International Journal of Medical Science 2016;3(10):1-8. ISSN:2393-9117.

[4] Vanderpump MPJ. Epidemiology of thyroid disease and swelling. In: Wass JAH, Stewat PM, eds. Oxford textbook of endocrinology and diabetes. $2^{\text {nd }}$ edn. Oxford University Press 2011: p. 358-69.

[5] Weetman AP. The thyroid gland and disorder of thyroid gland. In: Warrell DA, Cox TM, Firth JD, eds. Oxford text book of medicine. Vol. 2. $5^{\text {th }}$ edn. Oxford University Press 2010: p. 1826-50.

[6] Kartha PP, Sadasivan S. Spectrum of thyroid lesion and its clinicopathological correlation - a two year study from a tertiary care centre. Journal of Medical Science and Clinical Research 2017;5(7):25615-22.

[7] Maitra A. The endocrine system. In: Kumar V, Abbas KA, Aster CJ, eds. Robbins and Cotran pathologic basis of disease. Vol. 02. South Asia edition. New Delhi: RELX India Pvt Ltd., Publisher 2016: p. 1082-100. 